\title{
Mimics of Copper Proteins: Structural and Functional Aspects
}

\author{
ANA MARIA DA COSTA FERREIRA, MARIA LÚCIA PIRES DOS SANTOS, \\ ELEONICE MARIA PEREIRA, MARCOS OLIVEIRA DAMASCENO and WENDEL ANDRADE ALVES
}

\author{
Departamento de Química Fundamental, Instituto de Química, \\ Universidade de São Paulo, Cx. Postal 26077 - 05513-970 São Paulo, SP, Brasil \\ Manuscript received on September 8, 1999; accepted for publication on September 15, 1999; \\ presented by José M. RIVEROS
}

\begin{abstract}
The importance of copper as an essential element can be estimated by the wide range of copper proteins and enzymes playing different roles in biological systems. In the last decades many bioinorganic studies were developed on mimetic complexes of copper-dependent proteins, in order to verify the interrelations between structural and functional properties of active copper centers. Among the most studied copper ion ligand, diimine compounds have deserved special attention due their flexibility, facility of preparation, and ability to stabilize both oxidation states of this metal. In our laboratory, we have been investigating some Schiff base copper complexes as mimics of different proteins, with emphasis on functional aspects, trying to elucidate mechanisms of reaction, based on proposed intermediary species, in addition to molecular shapes. Particularly, mimics of the copper-zinc superoxide dismutase, and of monooxigenases and oxidases exhibiting dicopper sites are discussed in this work.
\end{abstract}

Key words: copper protein mimics, copper diimine complexes, EPR measurements, characterization and reactivity studies.

\section{INTRODUCTION}

The importance of copper as an essential element can be estimated by the wide range of copper proteins and enzymes playing different roles in biological systems (Kaim \& Rall 1996). Very recently, an upper limit of $10^{-18} \mathrm{~mol} / \mathrm{L}$ has been estimated for the concentration of free copper ions in the cell, which means that cellular pools of free copper are virtually nonexistent, and that copper ions are always inserted on suitable biomolecules (Lippard 1999). A wide range of different structures are exhibited by copper proteins and enzymes, depending on their

Correspondence to:

Ana Maria da Costa Ferreira

E-mail: amdcferr@quim.iq.usp.br occurrence, and activity.

In the last decades many bioinorganic studies were developed on mimetic complexes of copperdependent proteins. The characteristic structural features of the active sites in these proteins account for their particularly interesting spectroscopic properties that originated a prior useful classification (Adman 1991, Ferreira 1998). Based on these results, further studies were then carried out in order to verify the correlation between structural and functional properties of active copper centers, mainly through the preparation, and investigation of model compounds (Karlin \& Tyeklár 1993).

Among the most studied copper ion ligand, diimine compounds have been deserving special at- 
tention (Guerriero et al. 1995), due their flexibility, facility of preparation, and ability on stabilizing both oxidation states of this metal. These ligands can provide macroacyclic and macrocyclic structures, tripodal, compartmental, or dinucleating species (Fenton 1999). Most of the studies deal with structural parameters, such as binding distances and angles, in order to mimic activated states of enzymes, oxygenated intermediates, or special moieties in multimetallated proteins. In this case, model compounds are designed and isolated, having then their spectral and magnetic properties determined. On the other hand, some of the studies emphasize functional aspects, trying to elucidate mechanisms of reaction, based on proposed intermediary species, in addition to molecular shapes.

Particularly, dinuclear copper complexes have biological relevance, since they can give valuable information about the binding mode of dioxygen to the dicopper sites of proteins involved in its transport and activation, as for example: hemocyanin, tyrosinase, and laccase (Solomon et al. 1996). Since the pioneering studies on model systems for the action of copper monooxygenases (Karlin et al. 1984), and on oxygenated species of those proteins (Kitajima et al. 1989), investigations of this type of complexes have contributed to the better understanding of the oxygenation reactions in vivo.

Another protein extensively studied is the copper-zinc superoxide dismutase, mainly due their protective role in conditions of oxidative stress. This enzyme had its structure determined by X-ray crystallography, and its mechanism of action investigated by pulse radiolysis, showing a rate constant $\left(\mathrm{k} \cong 2 \times 10^{9} \mathrm{M}^{-1} \mathrm{~s}^{-1}\right.$ ) close to the diffusion limit (Fielden \& Rotilio 1984). Since its functional role has been described, many copper complexes with different ligands were prepared as mimics of this enzyme, specially macroacyclic polyimines (Gärtner \& Weser 1986). These studies indicated that the catalytic cycle requires a particular conformation of the active site, between a square planar arrangement adequate for copper(II) ions, and a distorted tetra- hedral form preferred by copper(I) ions.

In our laboratory, we have been investigating some Schiff base copper complexes as mimics of different proteins, involved in the metabolism of molecular oxygen and its reduced derivatives. A few examples are shown in Scheme 1. Complexes of tetradentate diimines seem to be more efficient on mimicking the SOD activity, while the tridentate ligands permit to obtain dinuclear species, which can act as monooxygenase or oxidase models.

\section{SOD MIMETIC COMPLEXES}

The cytosolic superoxide dismutase, $\mathrm{Cu}_{2} \mathrm{Zn}_{2} \mathrm{SOD}$, is an antioxidant protein that dismutates superoxide radicals into hydrogen peroxide and dioxygen (McCord \& Fridovich 1969). In its active center a monomeric copper ion is surrounded by four imidazole groups, one of them bridged to a zinc ion, with structural function.

In order to verify the effect of small structural differences on the SOD activity, we isolated some diimine copper(II) complexes, and investigated their reactivity towards oxygen reactive species (Santos et al. 1998). These compounds were prepared by condensation reactions of the corresponding parent carbonyl and amino compounds, according to procedures described in the literature, with suitable modifications (Fenton \& Vigato 1988). Their characterization was performed by spectroscopic techniques, including UV/Vis and EPR spectra, in addition to elemental analysis, magnetic susceptibility, and IR measurements. SOD activity was assayed by the inhibition of nitroblue tetrazolium (NBT) reduction, using xanthine/xanthine oxidase as the source of superoxide radicals, and monitoring the blue formazane product at $560 \mathrm{~nm}$ (Beauchamp \& Fridovich 1971). Based on the obtained kinetic results, the SOD activity of these compounds was estimated as the $\mathrm{IC}_{50}$ values (concentration corresponding to $50 \%$ of reaction inhibition), compared to that of the native enzyme, and of some known SOD mimics previously described in the literature (Müller et al. 1995), as shown in Table I. All the studied complexes 


\section{SCHEME 1}

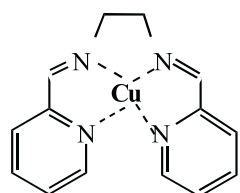

$\left[\mathrm{Cu}(\text { pyal-en) }]^{2+}\right.$

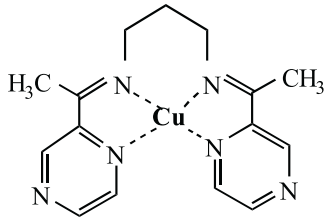

$[\mathrm{Cu}(\text { apz-pn) })]^{2+}$

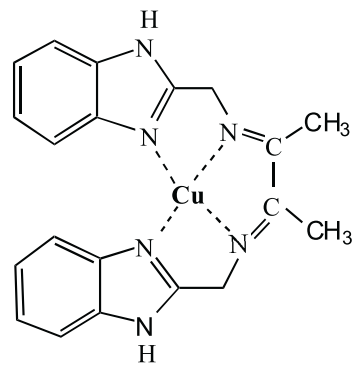

$\left[\mathrm{Cu}(\text { dac-ambi) }]^{2+}\right.$

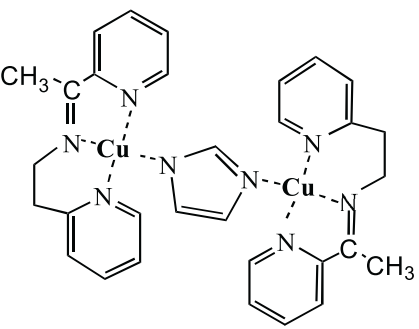

$\left[\mathrm{Cu}_{2}(\text { apy-epy })_{2} \mathrm{im}\right]^{3+}$

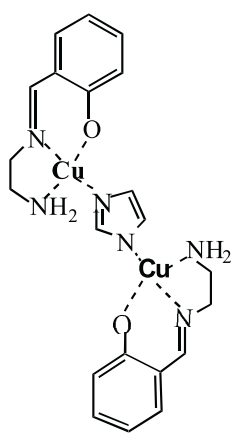

$[\mathrm{SECuImCuSE}]^{+}$<smiles></smiles>

$\left[\mathrm{Cu}_{2} \text { (aca-pol)Ac }\right]^{\cdot} \mathrm{H}_{2} \mathrm{O}$

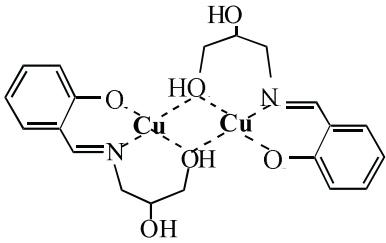

$\left[\mathrm{Cu}_{2}(\text { sal-pol })_{2}\right]^{2+}$

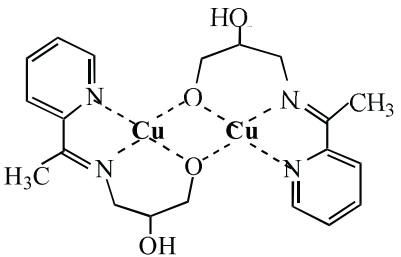

$\left.[\mathrm{Cu})_{2}(\text { apy-pol) })_{2}\right]^{2+}$ were shown to be good mimics of this enzyme, especially the compound $[\mathrm{Cu}(\mathrm{apz}-\mathrm{pn})]^{2^{+}}$(Santos et al. 1998). The calculated EPR parameters indicated an axial symmetry for all the complexes, similar to that of the native $\mathrm{Cu}_{2} \mathrm{Zn}_{2}$ SOD, which have a planar square configuration distorted toward tetrahedron. The extension of this tetrahedral distortion is usually estimated by the g/A ratio (Müller et al. 1995).

In addition, the studied models showed also some pro-oxidant properties, forming reactive radical species in the presence of biological oxidants, capable of damaging biomolecules (Santos et al. 1998). Further kinetic and mechanistic investiga- tions are currently being developed in our laboratory, in reactions of hydrogen peroxide and peroxynitrite, another biological oxidant (Santos et al. 1999).

\section{MIMICS OF PROTEINS WITH DICOPPER SITES}

Dinuclear copper complexes play an important role in many copper proteins, since coupled copper centers occur in the oxygen carrier hemocyanin, in tyrosinase, and in other multimetallated proteins (Kaim \& Rall 1996). Additionally, magnetic coupling phenomena in such complexes have been extensively studied in order to elucidate the magnetic 
TABLE I

Spectroscopic Parameters and SOD Activity of Some Diimine-Copper(II) Complexes, compared to that of native $\mathrm{Cu}_{2} \mathrm{Zn}_{2} \mathrm{SOD}$.

\begin{tabular}{|c|c|c|c|}
\hline $\begin{array}{l}\text { Compounds } \\
\text { (as perchlorate salts) }\end{array}$ & $\begin{array}{c}\text { d-d Band } \\
\lambda_{\max }, n m \\
\left(\varepsilon, M^{-1} \mathrm{~cm}^{-1}\right)\end{array}$ & $\begin{array}{l}\text { EPR Parameters }{ }^{\#} \\
\qquad \begin{array}{r}g \AA g^{n} g^{n} / A^{n} \\
(\mathrm{~cm})\end{array}\end{array}$ & $\begin{array}{c}\text { SOD activity } \\
\text { IC }_{50} \\
(\mu M)\end{array}$ \\
\hline$[\mathrm{Cu}(\text { dac-ambi })]^{2+}$ & $\begin{array}{c}710 \\
(101)\end{array}$ & $\begin{array}{r}2.0702 .235124 \\
2.247150\end{array}$ & 1.44 \\
\hline$[\mathrm{Cu}(\mathrm{PuPy})]^{2+*}$ & $\begin{array}{c}710 \\
(116)\end{array}$ & 2.0502 .225149 & 0.603 \\
\hline$[\mathrm{Cu}(\text { pyal-en })]^{2+* *}$ & $\begin{array}{c}630 \\
(106)\end{array}$ & 2.0582 .218117 & 0.446 \\
\hline$\left[\mathrm{Cu}(\text { dac-apbi) }]^{2^{+}}\right.$ & $\begin{array}{c}640 \\
(210)\end{array}$ & 2.0562 .248132 & 0.431 \\
\hline$[\mathrm{Cu}(\mathrm{PuPhePy})]^{2+*}$ & $\begin{array}{c}690 \\
(136)\end{array}$ & 2.0482 .217152 & 0.270 \\
\hline$[\mathrm{Cu}(\text { dac-aepy })]^{2+}$ & $\begin{array}{c}575 \\
(104)\end{array}$ & 2.0602 .218126 & 0.216 \\
\hline$\left[\mathrm{Cu}(\text { apz-pn) }]^{2+* *}\right.$ & $\begin{array}{l}646 \\
(60)\end{array}$ & 2.0632 .229113 & 0.0902 \\
\hline $\mathrm{Cu}_{2} \mathrm{Zn}_{2} \mathrm{SOD}^{*, * *}$ & $\begin{array}{c}680 \\
(150)\end{array}$ & 2.0832 .271162 & $\begin{array}{c}0.00589 \\
0.0143\end{array}$ \\
\hline
\end{tabular}

* Müller et al. 1995, Inorg. Chim. Acta, 233: 11-19.

** Santos et al. 1998, J. Inorg. Biochem., 71: 71-78.

\# EPR spectra were recorded in a Bruker EMX spectrometer, using frozen methanolic solutions. Diimine ligands: dac-apbi, derived from diacetyl and 2-(2-aminophenyl)benzimidazole; dac-aepy, derived from diacetyl and 2aminoethylpyridine; $P u P y$, derived from 2-pyridine carboxaldehyde and 1,4diaminobutane; $P u P h e P y$, derived from 2-benzoylpyridine and 1,4-diaminobutane.

spin-exchange mechanism (Hodgson 1975, Kahn 1987), that could explain catalytic electron transfers in biological systems. Dioxygen molecule can bind at these dinuclear copper active centers, and the structure elucidation of both the deoxygenated and the resulting oxygenated protein has been determined by spectral and EPR properties (Solomon et al. 1996). Several groups studied model compounds mimicking the most relevant aspects of those species, specially insertion of oxygen atoms in substrates (Sorrell 1989, Monzani et al. 1998), binding and activation of dioxygen in copper centers (Tol- man 1997, Karlin et al. 1997, Kitajima 1992).

In many copper proteins and enzymes, the imidazole ring is an essential metal binding site, and thus a wide variety of imidazole containing ligands have been investigated to mimic structural features of these biomolecules (Strothkamp \& Lippard 1982). In our case, some dinuclear copper complexes with a tridentate diimine ligand, in addition to an imidazole as the bridging ligand, were prepared, characterized, and had their catalytic properties investigated. Although they could be easily isolated as pure stable solids, species $[\mathrm{SECu}(\mathrm{im}) \mathrm{CuSE}]^{3+}$, 


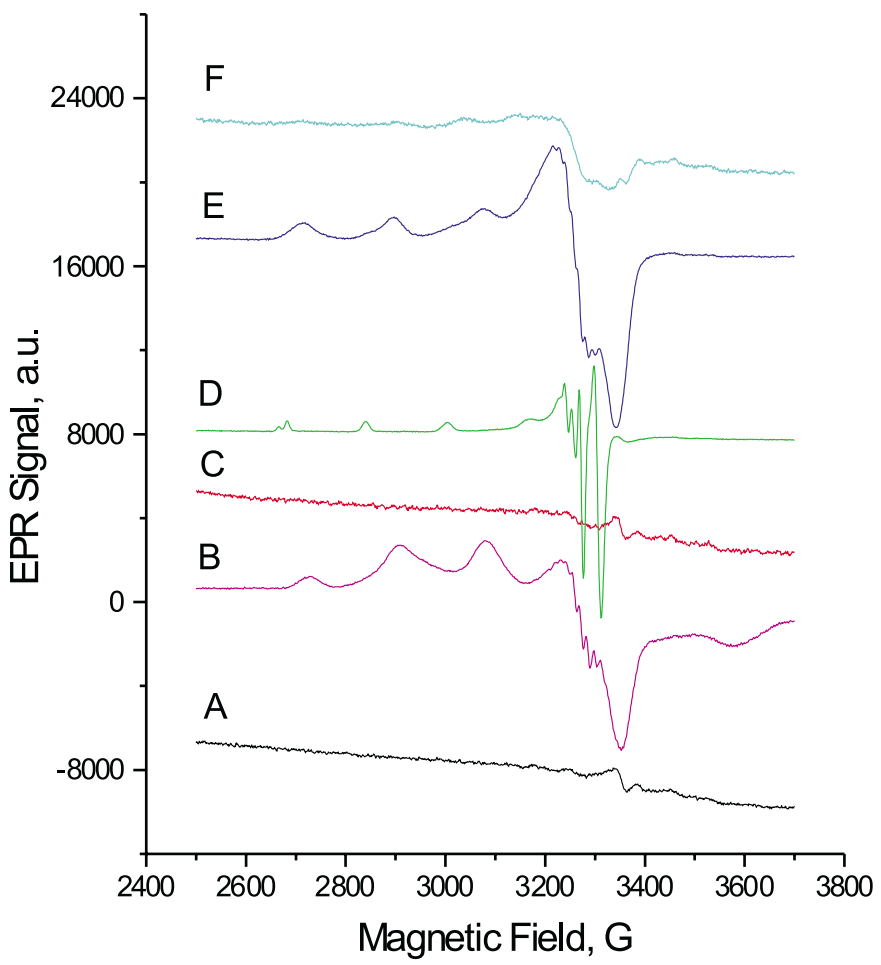

Fig. 1 - EPR spectra of some dinuclear diimine copper(II) complexes, in frozen methanol-water solution $(4: 1 \mathrm{v} / \mathrm{v})$, at $77 \mathrm{~K}$. A- solvent ; B$\left[\mathrm{Cu}_{2}(\text { apy-epy })_{2} \mathrm{im}\right]^{3+} ; \mathrm{C}-\left[\mathrm{Cu}_{2}(\text { sal-pol })_{2}\right]^{2+} ; \mathrm{D}-[\mathrm{Cu}($ aca-pol $) \mathrm{Ac}]$; E$[\mathrm{Cu}(\text { apy-pol })]^{+}$, monomer ; F- $\left[\mathrm{Cu}_{2}(\text { apy-pol })_{2}\right]^{2+}$.

$\left[\mathrm{Cu}_{2} \text { (apy-epy) }{ }_{2} \mathrm{im}\right]^{3+}$ and the corresponding monomers (see Scheme 1), they usually occur in solution as a monomer/dimer equilibrium, monitored by spectrophotometric changes, very dependent on the $\mathrm{pH}$ of solution. The monomers seem to be the predominant catalytic active species in reactions of hydrogen peroxide, since the rates of reaction showed an inverse dependence on the complex concentration for the studied systems. Probably, an available coordinating site for the oxidant is required.

All these compounds were found to be paramagnetic, similarly to their corresponding monomers, exhibiting characteristic EPR spectra (Figure 1). However, some other prepared dinuclear diimine complexes, as $\left[\mathrm{Cu}_{2}(\text { apy-pol })_{2}\right]^{2+}, \quad$ and $\left[\mathrm{Cu}_{2}(\text { sal-pol })_{2}\right]^{2+}$ compounds (see Scheme 1), showed a pronounced antiferromagnetic coupling in the solid state, or even a partial interaction in frozen solutions, as verified by EPR spectra (Figure 1, lines $\mathrm{C}$ and $\mathrm{F}$ ). These results were corroborated by magnetic susceptibility measurements.

\section{CONCLUSIONS}

The results obtained with the tetradentate diimine complexes showed that they are good models for the copper-zinc superoxide dismutase, exhibiting the characteristic distorted structure around the copper ion, as well as a marked SOD activity. A modulation of this activity can be supplied by small structural variations. On the other hand, the prepared dinuclear species are potential models for dicopper sites present in monooxygenases, or oxidases. Strong antiferromagnetic coupling was usually observed in these proteins, whose active center have similarities 
with that of the oxyhemocyanin. Additionally, dinuclear compounds can be interesting catalysts for reactions of hydrogen peroxide, occurring via twoelectron transfer, under investigation in our laboratory.

\section{REFERENCES}

Adman ET 1991. Copper Protein Structures. Adv Protein Chem 42: 145-197.

Beauchamp C \& Fridovich I 1971. Superoxide dismutase: improved assays and an assay applicable to acrylamide gels. Anal Chem 44:276-287.

Fenton DE 1999. Metallobiosites and their synthetic analogues - a belief in synergism. Chem Soc Rev 28: 159-168.

Fenton DE \& Vigato PA 1988. Macrocyclic Schiff base complexes of lanthanides and actinides. Chem Soc Rev 17: 69-90.

Fielden EM \& Rotilio G 1984. The structure and mechanism of $\mathrm{Cu} / \mathrm{Zn}$ superoxide dismutase. In: Copper Proteins and Copper Enzymes, LontiE R, ed., CRC Press, Boca Raton, vol. II, Cap. 2, pp. 27-61.

Ferreira AMDC 1998. Sítios Ativos em Proteínas de Cobre: Estrutura e Reatividade. Revista Universidade de Guarulhos - Ciências Exatas e Tecnológicas, III: $5-12$.

GärTNER A \& WeSER U 1986. Molecular and functional aspects of superoxide dismutases. Top Curr Chem 132: 1-61.

Guerriero P, Tamburini S \& Vigato PA 1995. From mononuclear to polynuclear macrocyclic or macroacyclic complexes. Coord Chem Rev 139: 17-243.

HodGson DJ 1975. The structural and magnetic properties of first-row transition-metal dimers containing hydroxo, substituted hydroxo, and halogen bridges. Progr Inorg Chem 19: 173-241.

KAHN O 1987. Magnetism of the heteropolymetallic systems. Struct Bonding (Berlin) 68: 89-167.

Kaim W \& Rall J 1996. Copper, a "modern bioelement". Angew Chem Int Ed Engl 35: 43-60.
KARLIN KD \& TYeKLÁR Z 1993. Bioinorganic Chemistry of Copper, Chapman and Hall, New York.

Karlin KD, Tolman WB, Kaderli S \& ZuberbüHLER AD 1997. Kinetic and thermodynamic parameters of copper-dioxygen interaction with different oxygen binding modes. J Mol Catalysis A: Chemical 117: 215-222.

Karlin KD, Hayes JC, Gultneh Y, Cruse RW, McKown JWW, Hutchinson JP \& Zubieta J 1984. Copper-Mediated Hydroxylation of an Arene: Model System for the Action of Copper Monooxygenases. J Am Chem Soc, 106: 2121-2128.

Kitajima N 1992. Synthetic approach to the structure and function of copper proteins. Adv Inorg Chem 39: $1-77$.

Kitajima N, Fujisawa K, Morooka Y \& Toriumi K 1989. $\mu-\eta^{2}: \eta^{2}$-Peroxo Binuclear Copper Complex, $\left[\mathrm{Cu}\left(\mathrm{HB}(3,5-\mathrm{iPr} 2 \mathrm{pz})_{3}\right)\right]_{2}\left(\mathrm{O}_{2}\right)$. J Am Chem Soc 111: $8975-8976$.

LipPaRd SJ 1999. Free Copper Ions in the Cell? Science 284: 748-749.

McCoRd JM \& Fridovich I 1969. Superoxide dismutase, an enzymic function for erythrocuprein. $J$ Biol Chem 244: 6049-6055.

Monzani E, Quinti L, Perotti A, Casella L, Gullotti M, Randaccio L, Geremia S, Nardin G, Faleschini P \& TABbi G 1998. Tyrosinase Models. Synthesis, structure, catechol oxidase activity, and phenol monooxygenase activity of a dinuclear copper complex derived from a triamino pentabenzimidazole ligand. Inorg Chem 37: 553-562.

Müller J, Felix K, Maichle C, Lengfelder E, Strahle J \& Weser U 1995. Phenyl-substituted copper di-Schiff base, a potent $\mathrm{Cu}_{2} \mathrm{Zn}_{2}$ SOD mimic surviving competitive biochelation. Inorg Chim Acta 233: 11-19.

Santos MLP, Faljoni-Alario A, Mangrich AS \& Ferreira AMDC 1998. Antioxidant and Prooxidant Properties of Some Diimine-Copper(II) Complexes. J Inorg Biochem 71: 71-78.

Santos MLP, Pereira EM \& Ferreira AMdC 1999. Catalytic activity of dimine copper complexes in the 
lipid peroxidation induced by peroxynitrite. In: $22^{a}$. Reunião Anual da SBQ, Poços de Caldas, MG. Resumo QI-157.

Solomon EI, Sundaram UM \& Machonkin TE 1996. Multicopper oxidases and oxygenases. Chem Rev 96: $2563-2605$.

SORRELL TN 1989. Synthetic models for binuclear copper proteins. Tetrahedron 45: 3-68.
StrothKamp KG \& LiPPARD SJ 1982. Chemistry of the imidazole-bridge bimetallic center in the $\mathrm{Cu}-\mathrm{Zn}$ SOD and its model compounds. Acc Chem Res 15: 318-326.

ToLman WB 1997. Making and breaking the dioxygen O-O bond: new insights from studies of synthetic copper complexes. Acc Chem Res 30: 227-237. 